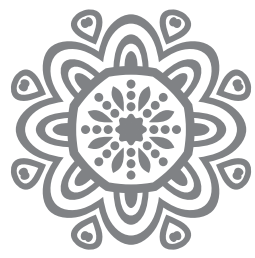

\title{
Transmisi Wahyu: \\ Antara Filsafat Takwil Nasr Hamid Abu Zaid dan Teori “Message Production” Ilmu Komunikasi
}

\author{
Mulawarman Hannase \\ Dosen Institut Perguruan Tinggi Ilmu al-Qur'an (PTIQ) Jakarta \\ HP. 081284688941
}

\begin{abstract}
Abstrak: Tulisan ini merupakan sebuah upaya untuk mengintegrasikan berbagai teori-teori ilmu pengetahuan modern, khususnya teori ilmu komunikasi, dengan metode penafsiran al-Qur'an yang dikembangkan oleh Nasr Hâmid Abû Zaid yaitu teori takwil al-Qur'an. Studi ini menemukan bahwa tipologi teori takwil yang dikonstruksi oleh Nasr Hâmid Abû Zaid begitu menekankan pentingnya memperhatikan peran pengarang dari teks, penafsir serta konteks, sebagai teori menafsirkan al-Qur'an. Setelah dibandingkan, teori ini nampak jelas sejalan dengan pandangan teori ilmu komunikasi modern yang dikembangkan oleh Katherine Miller. Adapun pendekatan yang digunakan dalam studi ini adalah pendekatan hermeneutik dalam rangka memahami transmisi dan interpretasi teks-teks agama yang dianggap relevan dengan teori produksi pesan dalam ilmu komunikasi.
\end{abstract}

Kata Kunci: Abu Zaid, Message Production, takwil

\section{A. Pendahuluan}

Dalam berbagai literatur ilmu tafsir, penafsiran al-Qur'an memiliki dua metode yang populer, yakni tafsir bi al-ma'tsûr (menggunakan riwayat) dan tafsir bi al-ra'yi (menggunakan pendapat atau bisa juga disebut ta'wil). Penafsiran pertama cenderung rigid sementara penafsiran kedua cenderung luwes dan terbuka. Salah satu tokoh yang menegaskan perlunya takwil adalah seorang pemikir asal Mesir Nasr Hâmid Abû Zaid. Ia merekomendasikan perlunya melaku- 
kan takwil terhadap ayat-ayat al-Qur'an dalam rangka pemahaman yang lebih komperhensif terhadap makna-makna al-Qur'an. ${ }^{1}$

Permasalahan yang menjadi perhatian utama dalam tulisan ini adalah dapatkah teori-teori ilmu pengetahuan modern seperti ilmu komunikasi disandingkan dengan teori-teori studi al-Quran yang dikonstruksi oleh para ulama dan pemikir dalam bidang filsafat seperti teori takwil? Pemikiran takwil Nasr Hâmid Abû Zaid yang menekankan perlunya dialektika antara teks dan konteks di samping pemahaman terhadap struktur linguistik teks, telah banyak dikaji sebagai sebuah metode menafsirkan al-Qur'an dalam rangka pemaknaan yang membumi terhadap al-Qur'an. Pada intinya, struktur teks yang ada dalam alQur'an bermuara pada sebuah simpulan bahwa teks-teks al-Qur'an merupakan risalah (pesan) Tuhan kepada manusia yang wajib dipahami.

Senada dengan itu, pesan (message) dalam ilmu komunikasi memiliki kedudukan yang sangat penting, mengingat komunikasi itu sendiri adalah proses pernyataan antar manusia atau proses penyampaian pesan dari komunikator kepada komunikan. Oleh karena itu, Katherine Miller dalam teori-teori ilmu komunikasinya menganggap prouksi pesan (Message Production) sebagai salah satu teori yang harus dikaji dalam rangka pendalaman terhadap ilmu komunikasi. Ia mengatakan "Tidak diragukan lagi bahwa proses pengembangan produksi pesan merupakan sentral dari interaksi komunikasi”.

Dalam tulisan ini, penulis mencoba membandingkan filsafat Takwil Nasr Hâmid Abû Zaid dengan terori message production tentang problematika penyampaian pesan teks wahyu sebagai representasi Tuhan di muka bumi ini. Teori ilmu komunikasi, kaitannya dengan proses pembuatan pesan, menurut penulis menarik untuk dikaji secara paraler dengan teori penyampaian teks wahyu dalam Islam. Oleh karena itu, pada tahap akhir tulisan ini, penulis mengilustrasikan beberapa bentuk kolerasi antara teori-teori produksi pesan ilmu komunikasi dan konsepsi teks wahyu dalam tradisi Islam.

\section{B. Tradisi Wahyu dalam Islam}

\section{Wahyu Sebagai Pesan adalah Proses Komunikasi}

Proses komunikasi wahyu baik yang bersifat simbolik maupun langsung banyak sekali didapatkan di dalam al-Qur'an. Salah satunya adalah yang pernah terjadi antara Maryam dan kaumnya setelah ia melahirkan Isa, ketika ia takut

${ }^{1}$ Pendekatan Penafsiran ini bisa ditelurusi dalam beberapa karya ulumul Qur'an yang telah ditulis oleh banyak Pakar. Di antaranya adalah karya al-Zarqasyi, al-Burhân fî̀ 'Ulûm al-Qurân. Kairo: Dar al-Turath. 
menghadapi masyarakatnya sehingga ia pun kemudian berjanji untuk tidak berbicara sebagaimana yang dinasihatkan kepadanya.

"Maka Maryam membawa anak itu kepada kaumnya dengan menggendongnya. Kaumnya berkata: "Hai Maryam, Sesungguhnya kamu Telah melakukan sesuatu yang amat mungkar. Hai saudara perempuan Harunayahmu sekali-kali bukanlah seorang yang jahat dan ibumu sekali-kali bukanlah seorang pezina", Maka Maryam menunjuk kepada anaknya. mereka berkata: "Bagaimana kami akan berbicara dengan anak kecil yang masih di dalam ayunan?"2

Isyarat Maryam kepada Isa yang masih kecil mengandung pesan yang intinya: “janganlah kalian bertanya kepadaku, bertanyalah kepadanya". Pesan tersebut ditangkap oleh kaumnya sehingga jawaban mereka, "Bagaimana mungkin kita dapat berbicara dengan seorang bayi”. Pesan yang terdapat dalam isyarat Maryam kepada kaumnya menjadikan isyarat tersebut sebagai "wahyu", sebagaimana isyarat Zakaria kepada kaumnya ketika ia meminta mereka untuk bertasbih. $^{3}$

Dari contoh tersebut, Nasr ㅂ̂amid Abû Zaid menjelaskan bahwa, makna sentral dari pemberian wahyu adalah pemberian informasi. Wahyu adalah sebuah hubungan komunikasi antara dua pihak yang mengandung pemberian informasi atau pesan. Apabila dalam proses komunikasi apapun pemberian informasi dapat berlangsung hanya melalui media khusus, maka sudah dapat dipastikan bahwa konsep media telah terkandung dalam konsep wahyu, dan media yang digunakan dalam proses komunikasi dan informasi itu merupakan media bersama antara pengirim dan penerima. Maksudnya dua pihak terlibat dalam proses komunikasi wahyu tersebut. ${ }^{4}$

Teks sebagai pesan berarti bahwa masyarakat yang menjadi sasarannya adalah seluruh manusia, manusia yang terkait dengan sistem bahasa yang sama dengan teks, dan yang terkait dengan peradaban di mana bahasa tersebut sebagai sentralnya. Konsep penurunan teks dinamakan tanzil dipahami dengan penurunan kepada manusia melalui perantara: pertama, malaikat dan kedua, Muhammad yang berbentuk manusia. Risalah ini merupakan risalah dari langit ke bumi namun ia bukanlah risalah yang terlepas dari hukum-hukum realitas dengan segala apa saja yang terstruktur dalam realitas tersebut, khususnya struktur budaya. ${ }^{5} \mathrm{Di}$ sini akan dipetakan proses pewahyuan menjadi dua versi:

\footnotetext{
${ }^{2}$ QS. Maryam 19: 27-29.

${ }^{3}$ Lihat Nasr Hâmid Abû Zaid, Mafhûm An-Nash, Dirâsah fî al-'Ulûm al-Qurân. Beirût: Markaz al-Tsaqâf al-'Arabi, 2000. Hal. 1-5.

${ }^{4}$ Nasr Hâmid Abû Zaid, Mafhûm An-Nash, hal. 34

${ }^{5}$ Nasr Hâmid Abû Zaid, Mafhûm An-Nash, hal. 69.
} 


\section{Versi Kesarjanaan Islam}

Para sarjana muslim berkeyakinan bahwa pengumpulan al-Qur'an mempunyai dua arti, yakni melalui proses pengahafalan dan proses penulisan. Proses penumpulan tercatat setidaknya melalui tiga fase kesejarahan. Pertama, pada masa Nabi; kedua, masa Abu Bakar; dan ketiga, masa Usman. Pijakan keyakinan sarjana Muslim tidak lain adalah riwayat yang telah mengalami proses seleksi yangketat.

Ibnu Abbas sebagai tokoh yang dianggap sangat otoritatif dalam studi al-Qur'an dari kalangan sahabat memberi klarifikasi bahwa al-Qur'an diturunkan dari lauhulmahfudz ke baitil'izzah (langit dunia) sekaligus pada malam lailat al-qadr, setelah itu wahyu disampaikan secara berangsur-angsur kepada Nabi Muhammad selama masa kenabiannya. ${ }^{6}$

Proses turunnya wahyu dari Allah yang ditujukan kepada manusia melibatkan dua pihak sebagai perantara, Malaikat Jibril mewakili Allah dan Rasulullah sebagai pihak penerima mewakili manusia. Lalu bagaimana Jibril menerima titipan Allah berupa al-Qur'an untuk disampaikan kepada Muhammad, dan bagaimana pula ia menerimanya dari jibril. ${ }^{7}$

Al-Zarqâni menjelaskan bahwa yang dibawa Malaikat Jibril kepada Nabi Muhammad adalah al-Qur'an dalam arti lafadz-lafadz yang sekaligus menjadi mu'jizat, mulai dari surah al-fatihah sampai akhir surah an-Nas. Lafadz-lafadz tersebut secara murni merupakan firman Tuhan tanpa ada sedikitpun campur tangan baik oleh Jibril Maupun Muhammad. Oleh karena itu al-Qur'an hanya boleh dinisbahkan sebagai kalam-Nya, tidak kepada yang lain. Sungguh keliru jika ada yang beranggapan bahwa Malaikat Jibril hanya menerima al-Qur'an dalam bentuk makna kemudian diungkapkan oleh Rasulullah dalam bahasa Arab, atau bahwasanya yang merangkai bahasa al-Qur'an adalah malaikat jibril sendiri. Setelah menerima secara penuh dari Allah, lalu kemudian disampaikan kepada Muhammad secara berangsur-angsur dengan proses dan motif penyampaian yang beraneka ragam. ${ }^{8}$

Pada saat Nabi saw. wafat sama sekali belum ada teks yang terkodifikasi. Teks-teks al-Quran masih berceceran di tangan para sahabat baik berupa catatan-catatan pribadi maupun hafalan yang mereka miliki. Atas dasar itulah Abu Bakar berinisiatif untuk melakukan kodifikasi untuk pertama kalinya, mengingat juga ada kekhawatiran banyaknya sahabat yang wafat pasca peristiwa Yamamah. Setelah masa Abu Bakar, yaitu pada masa Usman, al-Qur’an kembali dikodifika-

\footnotetext{
${ }^{6}$ Mannâ' al-Qatthân, Mabahits fî̀ 'Ulûmi al-Qur'ân, hal. 101

${ }^{7}$ Sahiron Syamsuddin DKK, Heremeneutika al-Qur'an. Yogyakarta: Islamika, 2003, hal. 9.

${ }^{8}$ Az-Zarqânî, Manâhil al-'Irfân, hal. 46
} 
si untuk yang kedua kalinya. Akan tetapi antara kodifikasi yang dilakukan oleh Abu Bakar dengan yang dilakukan oleh Usman berbeda. Jika pengumpulan pada masa Abu Bakar masih menggunakan dialek-dialek yang dilegalisasi oleh Nabi dalam tujuh huruf (sabjah a hruf), maka pengumpulan yang dilakukan oleh Usman sudah diseragamkan hanya dalam satu dialek, yakni dialek Quraisy. Hal ini disebabkan karena konsiderasi munculnya kebijakan Usman adalah perseteruan umat tentang perbedaan cara baca. ${ }^{9}$

Mushaf yang dikumpulkan pada masa Usman atau yang dikenal dengan Mushaf Usmani adalah bentuk final dari redaksi al-Qur'an. Tiga fase yang dilewati, baik masa Nabi, Abu Bakar dan Usman, merupakan fase yang berhubungan serta diliputi proses seleksi ketat dalam menerima teks dari para penghafal dan pemilik koleksi pribadi. Oleh karena itu, keyakinan para sarjana muslim atas keutuhan dan keorisinilan mushaf Usman sebagai format redaksi final wahyu bukannya tanpa pijakan yang jelas seperti yang didengaunkan para safjana barat. ${ }^{10}$

\section{Versi Kesarjanaan Barat}

Sejarah teks al-Qur'an adalah salah satu obyek kajian dalam beberapa lingkup kesarjanaan barat yang telah dimulai sejak abad kedua belas dan telah melahirkan banyak karya kesarjanaan.

Secara umum, sasaran kritik barat terhadap mushaf al-Qur'an tertuju pada tiga fase kesejarahan. Pertama, koleksi dan susunan teks dari lisan sampai tulisan. Kedua, perbedaan tata cara baca dan beberepa kodeks sahabat. Ketiga, proses pemantapan teks dan cara baca menjadi kanonik. Fase pertama diawali dengan asumsi yang meyakinkan bahwa pada saat Nabi wafat sama sekali belum ada teks yang terkodifikasi. Teks-teks al-Quran masih berceceran di tangan para sahabat baik berupa catatan-catatan pribadi maupun hafalan yang mereka miliki. Kepedulian terhadap teks tersebut, menurut salah satu riwayat, bermula dari pecahnya tragedi Yamamah pada tahun 12 hijriah yang menewaskan sejumlah besar penghafal al-Qur'an. Pada saat inilah atas usulan Umar kepada khalifah abu bakar al-Qur'an dikodifikasi. ${ }^{11}$

Pada masa Usman, al-Qur'an disatukan dan diseragamkan dalam satu mushaf. Akan tetapi naskah kodifikasi mushaf ini masih telanjang dengan tanda akhir surat, namun belum terdapat tanda-tanda khusus untuk membedakan bunyi huruf tertentu. Dengan kata lain tulisan yang digunakan belum menggu-

\footnotetext{
${ }^{9}$ Sahiron Syamsuddin DKK, Heremeneutika al-Qur'an, hal. 9.

${ }^{10}$ Sahiron Syamsuddin DKK, Heremeneutika al-Qur'an, hal. 4

${ }^{11}$ Sahiron Syamsuddin DKK, Heremeneutika al-Quran, hal. 5
} 
nakan tanda titik untuk membedakan huruf ba dan ta misalnya. Keseluruhan fragmen manuskrip ini diyakini belum ada yang tertulis sebelum abad 2 Hijriah, malahan diprediksikan setelah abad 3 Hijriah. ${ }^{12}$

Dengan demikian, peneliti barat mengalami kesulitan untuk meyakini bahwa bahwa mushaf al-Qur'an yang ada merupakan salinan langsung dari mushaf Usman. Kesulitan seperti ini mendorong peneliti barat untuk mempertanyakan riwayat-riwayat yang menginfirmasikan koleksi-koleksi pribadi para sahabat pra-mushaf Usman. Paling tidak ada dua nama yang melontarkan kritik cukup pedas, yakni John Burton dan John Wansbrough. Burton menegaskan bahwa seluruh riwayat yang menceritakan kodeks para sahabat dan kodeks yang berdar di beberapa kota metropolitan muslim saat itu, sebenarnya telah dipalsukan oleh para fuqaha dan filolog muslim kemudian. Hal ini, menurut Burton, dimaksudkan untuk dijadikan setting kisah kodifikasimushaf Usman, yang pada gilirannyadijadikan penutup kenyataan bahwa Muhammad sensiri telah mengumpulkan dan mengecek edisi final al-Qur'an.

Itulah salah satu ilustrasi tentang model studi Barat terhadap al-Qur'an. Pada dasarnya, studi al-Qur'an di Barat tidak memiliki keseragaman suara dalam model keraguan terhadap sejarah teks al-Qur'an. Sebab, meski mereka bersikap kritis terhadap keyakinan-keyakinan muslim akan keutuhan wahyu yang terkodifikasi, namun pada umumnya mereka menerima kebenaran pengumpulan al-Qur'an, baik yang dilakukan oleh Abu Bakar maupun Usman. Mereka yang benar-benar melawan arus mainstream berkenaan dengan kelengkapan alQur'an, adalah John Burton dan John Wansbrough. Keduanya, dengan pendekatan dan tesis yang berbeda, sama-sama berkeinginan menggolkan skeptisisme terhadap al-Qur'an secara terang-terangan.

\section{Takwil Nasr Hâmid Abû Zaid sebagai Metode Menafsirkan Pesan Wahyu}

Dalam khazanah klasik khususnya dalam penafsiran teks al-Qur'an terdapat pemisahan antara apa yang disebut dengan tafsir bi al-ma'tsuûr ${ }^{13}$ dengan apa yang disebut denga tafsir bi ar-ra'yi ${ }^{14}$ atau takwil.

Tafsir bi al-ma'tsur bertujuan mencapai makna teks melalui sejumlah dalil historis (periwayatan) dan kebahasaan yang membantu untuk memahami teks secara obyektif, yakni seperti yang dipahami oleh mereka yang sezaman

\footnotetext{
${ }^{12}$ Sahiron Syamsuddin DKK, Heremeneutika al-Qur'an, hal. 9

${ }^{13}$ Nasr Hâmid Abû Zaid, an-Nash, as-Sulthah, al-Haqîqah, diindonesiakan menjadi Teks Otoritas Kebenaran. Yogyakarta: LKiS, 2003, hal. 87.

${ }^{14}$ Nasr Hâmid Abû Zaid, Isykâliyyah al-Qirẩah wa âliyât al-Ta’wîl. Beîrût: al-Markaz asTsaqâfiî al-'Arabî, 1994, hal. 17.
} 
dengan turunnya teks ini melalui berbagai gejala kebahasaan yang tekandung dalam teks dan dipahami oleh sejumlah orang. Sedangkan tafsir bi al-ra'yi atau takwil dipandang atas dasar obyektif, karena sang mufassir tidak mulai dari fakta-fakta historis dan gejala kebahasan, akan tetapi mulai dari sikap aslinya, lalu berupaya mencoba menemukan sikapnya ini dalam al-Quran. ${ }^{15}$

Masing-masing dari kedua kecenderungan tersebut berusaha untuk memahami dan menangkap maksud Tuhan yang tersirat dan tersurat dalam teksteks agama (al-Quran). Para pendukung kecendrungan menafsirkan teks-teks al-Qur'an dengan metode bi al-ma'tsûr menamakan dirinya dengan ahlussunnah dan salaf shaleh. Menurut Nasr Hamid kelompok ini cenderung mengabaikan dan memarjinalkan enksistensi mufassir lantaran teks dan beberapa fakta historis (riwayat) dan kebahasaannya. Tipe kedua, tafsir bi ar-ra'yi boleh di kata sebagai kelompok penafsir modern. Perbedaan mendasar dari kedua kelompok ini adalah bahwa penafsir bi al-ra'yi menafsirkan al-Qur'an dengan merujuk pada riwayat-riwayat atas penafsiran Rasul dan para sahabat sedangkan penafsir bi al-ma'tsûr nenafsirkan al-Qur'an berdasarkan mekanisme kebahasaan dan konteks. ${ }^{16}$

Fenomena di atas menurut Nasr Hamid memerlukan kerja keras untuk melakukan pembacaan terhadap teks untuk menghasilkan hasil pembacaan yang lebih membumi dan realistis. Dalam melakukan pembacaan terhadap teks, bagi Nasr Hamid, tidak terelakkan lagi harus menggunakan sebuah metode yang ideal danlebih berani yang ia sebut sebagai takwil (hermeneutika).

Berdasarkan teori penafsiran hermeneutik, ada tiga unsur penting yang harus diperhatikan, yaitu apa yang disebut dengan triologi (pengaran/teks kritikus)atau (tujuan/teks/tafsir). Dalam menemukan hubungan antara ketiganya metode takwil atau hermeneutik diperlukan karena ia memiliki mekanisme kerja yang menganalisa hubungan organik antara ketiga unsur tersebut. Hermeneutika diasumsikan sebagai metode takwil yang bisa mengeliminir beberapa kesulitan dalam memahami teks sehingga pada gilirannya hermeneutika memberikan fundamen baru terhadap hubungan antara ketiga unsur tersebut.

Dari ilustrasi di atas bisa kita tangkap bahwa pertanyaan mendasar yang ingin dijawab oleh hermeneutik -khususnya dalam bidang kritik sastra- yang mencoba unutk diadopsi oleh Nasr Hamid menjadi metode penafsiran teks agama (al-Qur'an) adalah, bagaimana hubungan antara pengarang dengan teks? Apakah teks dapat benar-benar disetarakan dengan tujuan pengarang? Jika hal

\footnotetext{
${ }^{15}$ Nasr Hâmid Abû Zaid, Isykâliyyah al-Qirẩah wa âliyât al-Ta’wîl, hal. 15.

${ }^{16}$ 'Ali Harb, al-Ta’wîl wa al-Haqîqah. Beîrût: al-Markaz as-Tsaqâfî̀ al-'Arabî, hal. 56.
} 
ini benar apakah seorang kritikus atau mufassir bisa meposisikan dirinya sebagai eksekutor terhadap dunia intelektual pengarang melalui analisis teks?

Untuk menjawab pertanyaan-pertanyaan tersebtu salah satu pemikiran hermeneutika yang metodenya bisa diadopsi ke dalam penafsiran teks al-Qur'an adalah hermeneutika yang dibangun oleh Schleiermacher (1843). ${ }^{17}$ Hermeneutika schleiermacher berpijak pada prinsip dasar bahwa teks merupakan ekspresi perangkat linguistik yang mentransformasikan ide-ide pengarang kepada pembaca. Oleh karena itu dalam rangka untuk sampai pada pemahaman teks yang ideal perlu dipahami perangkat linguistik dan kondisi pengarang karena hubungan antara keduanya adalah hubungan yang bersifat dialektis. Setiap kali teks muncul dalam waktu, maka ia menjadi samar-samar bagi kita sehingga yang terjadi, kita lebih dekat kepada kesalah pahaman bukan pada pemahaman yang sebenarnya. ${ }^{18}$

Oleh karena itu, untuk mengakses makna teks seorang mufassir membutuhkan dua kompetensi, yakni kompetensi linguistik dan kemampuan untuk mengakses alam kemanusiaan. Kompertensi linguistik sendirian tidak cukup karena manusia tidak dapat mengenali wilayah bahasa yang nondefenitif. Demikian pula kompetensi dalam mengakses dalam mengakses alam kemanusiaan tidak cukup, karena kompetensi ini tidak pernah sempurna. Oleh karenanya harus berpegang pada kedua aspek ini dalam menafsirkan sebuah teks. Kedua aspek di atas (linguistik dan psikis) adalah merupakan perpaduan antara aspek obyektif dan subyektif, dan sangat erat kaitannya pula dengan kajian historis dan strukturalis. Tanpa keduanya seseorang tidak mungkin bisa terhindar dari kesalahpahaman. Sehingga menurut sclheiermacher signifikansi hermeneutik adalah memahami teks sebagaimana yang dipahami oleh penulisnya, bahkan hingga lebih baik dari apa yang dipahami oleh pengarangnya.

Problem lain yang berusaha untuk dikaji oleh Nash Hamid dalam proyek takwilnya adalah hubungan antara teks dan konteks. ${ }^{19}$ Menurut Nasr Hamid penafsiran teks dalam wacana keagamaan banyak mengabaikan konteks. Padahal menurut dia, interpretasi yang bisa menghasilkan makna teks menutut pengungkapan makna melalui analisis atas berbagai level teks.

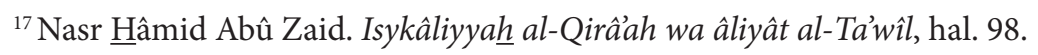

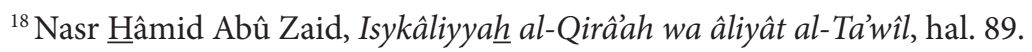

${ }^{19}$ Teori relasi konteks berperan sangat penting dakam pemaknaan teks. Gagasan yang pada awalnya dipelopori oleh Schleiermacher ini dimasukkan dalam teori geiteswissechaften oleh Wilhelm Dilthey kemudian dimasukkan dalam beberapa konteks berikut: "konteks kehidupan", "konteks makna", dan "konteks interaksi". Nasr Hâmid Abû Zaid, an-Nash, as-Sulthah al-Haqîqah, diindonesiakan menjadi Teks Otoritas Kebenaran, hal. 96.
} 
Bagaimanapun teks agama tidak terpisah dari struktur budaya tempat ia terbentuk. Di samping itu, teks tidak mengesampingkan sama sekali hakikat kebenarannya sebagai teks linguistik. Struktur budaya dijadikan sebagai faktor eksternal teks, sedangkan struktur kebahasaan sebagai faktor internal teks. Faktor-faktor internal ditemukan pada kondisis-kondisi atau problem kultural masyarakat yang menjadi sebab turunnya teks (asbab an-nuzul) sedangkan faktor internal ditekankan pada konteks wacana kebahasaan seperti, majâz, istiârah, tamzîl, tasybîh dan kinâyah.

Salah satu contoh penafsiran ayat al-Qur'an: ومن لم يككم بما أنزل الله فألكك هم الكافرون. Ulama tafsir klasik menafsirkan ayat ini sebagai perintah untuk menjadikan Islam berserta ajaran-ajarannya sebagai sistem pemerintahan dan konstitusi negara. Alasannya adalah karena kata حكم diartikan sebagai pemerintahan.

Akan tetapi Nasr Hamid memandang bahwa adanya pengulangan antara kata بين mempertegas bahwa arti hukum adalah memisahkan antara orang-orang yang bertikai. Adanya kata بين menunjukkan bahwa hukum berada pada level struktur dalam (deep structure) yang artinya di antara orang-orang yang bertikai. Andaikan yang dimaksud adalah makna politis sebagaimana yang dipahamai oleh para mufassir klasik, maka struktur linguistiknya akan menempuh metode stilistik, sehingga menjadi وأخكمه atau فاحمه ani berarti bahwa hukum berkaitan erat dengan kasus tertentu, yaitu perselisihan, maka tidak ada hegemoni terhadap hukum dengan apa yang Allah turunkan.

Kemudian dilihat dari konteks turunnya ayat ini, berkaitan dengan perselisihan yang terjadi di antara orang-orang Yahudi akibat pemalsuan, perusakan dan penyelewengan. Sebagian mereka mempercayakan proses hukum kepada nabi. Teks tersebut memberikan pilihan kepada nabi antara menghukumi di antara mereka atau berpaling dari mereka. Di sini penulis mengutip beberapa statemen dari tokoh pemikir Islam kontemporer mengenai al-Qur'an dan perihal identitasnya sebagai wahyu. ${ }^{20}$

\section{Teori Produksi Pesan (Message Production)}

S.R Wilson (1997) mensinyalir bahwa sejak tahun 1982 terma message production telah dipakai sebagai formulasi framework dalam upaya memahami dan memperdalam kajian ilmu komunukasi. Sejak saat itu telah diterbitkan beberapa karangan tentang teori ini (e.g., Cody and McLaughlin, 1990; Dillard, 1990a, Greene, 1997b) dan beberapa Jurnal (e.g. Human Commudication Research, 1989 Vol. 10, No. 1; Communication Theory, 2000, Vol. 10, No. 2. Semua

\footnotetext{
${ }^{20}$ Kutipan-kutipan ini disadur dari makalah Adian Husani dan Adnin Armas pada Workshop Pemikiran Islam Kontemporer Sabtu-Senin, 11-13 Februari 2006 di Kairo.
} 
itu merupakan upaya dalam memberikan sumbangsih terhadap pengembangan interaksi komunikasi.

Upaya-upaya pengkajian dan pengembangan teori produksi pesn tersebut bertujuan untuk memperjelas bagaimana proses produksi pesan bisa kita pahami, sejauh mana peran kognisi dalam produksi pesan, bagaimana produksi pesan itu terjadi dan kenapa kita terkadang memproduksi pesan-pesan tertentu dengan tujuan-tujuan tertentu. Di antara teori produsi pesan yang terkenal adalah teori konstruksivisme. ${ }^{21}$

Konstruktivisme adalah sebuah model teori dalam pengembangan ilmu komunikasi yang dikembangkan oleh Jesse Delia pada tahun tujuh puluan. Anggapan inti dari constructivism adalah bahwa seseorang akan menggambarkan dunia melalui sistem dari gagasan mereka sendiri. Gagasan-gagasan berupa komponen-komponen kognitif yang dilengkapi atas realita-realita yang ada. ${ }^{22}$

Dalam teori Konstruksivisme ada teori Role Category Questionaire (RCQ) yang dibuat sebagai sample gagasan-gagasan interpersonal untuk menjelaskan suatu makna. Gagasan-gagasan membedakan ciri-ciri yang kita gunakan untuk mengklasifikasikan persepsi. RCQ dalam penggunaannya selanjutnya untuk sebuah penelitian menekankan pada kepribadian dan tindakan seseorang dalam mendefinisikan karakter seseorang bukan secara fisik. Peneliti yang menggunakan RCQ berusaha untuk menentukan derajat kompleksitas kognitif responden sebagai bentuk kesan interpersonal mereka.

Di dalam proses kognitif yang berlangsung pada diri seseorang terdapat dua macam, yaitu yang pertama belum matangnya proses kognitif ketika dia hanya melihat orang lain dari sisi hitam atau putih saja. Yang kedua adalah individu yang telah memiliki kedewasaan, dia melihat dunia dari gambaran kehidupan yang ada, dan mampu mengambarkan orang dengan lebih kompleks, bahwa tidak hanya terpaku pada hitam ataupun putih saja.

Teori lainnya adalah Person-Centered Message (Person sebagai sentral pesan). Bernstein (1975) dengan teori sosiologisnya memposisikian individu sebagai sentral orientasi disamping posisi (kedudukan) sebagai sentral orientasi. ${ }^{23}$ Yang pertama dipakai untuk mengelaborasi simbol-simbol yang mewakili intensi, perasaan dan persepsi seseorang. Sedangkan yang kedua dipakai untuk nenentukan dan membatasi norma-norma dan aturan budaya pada kondisi tertentu. Bernstein mengungkapkan bahwa Person-Centered Message sebagai pe-

${ }^{21}$ Katherine Miller, Communication Theories, Perspectives, Procces, and Contexts. New York: McGraw Hill International Edition, 2005, hal. 104

${ }^{22}$ Katherine Miller, Communication Theories, hal. 107.

${ }^{23}$ Katherine Miller, Communication Theories, hal. 108. 
san yang secara reflek dan adaptif pada subyek. Ia mengungkapkan bahwa Person-Centered Message ditujukan pada kompleksitas kognitif.

Di samping itu, ada juga teori desain pesan $\operatorname{logis}^{24}$ Terdapat tiga macam Desain Pesan Logis, diantaranya:

1. Expresive Desain Logic, yaitu bahwa bahasa merupakan media untuk mengekspresikan pikiran dan perasaan. Mereka hanya berpikir dan merasakan, yang lainnya akan mengetahui apa yang mereka pikirkan dan rasakan.

2. Conventional Design Logic, yaitu bahwa komuniasi merupakan permainan secara bersama, sesuai pada hukum-hukum dan prosedur sosial konvensional.

3. Rhetorical Design Logic, yaitu komunikasi merupakan kreasi dan negosiasi dari pribadi sosial dan situasi yang ada. Artinya ketika seseorang menyampaikan gagasannya mereka mengungkapkn kenyataan-kenyataan sosial yang ada. ${ }^{25}$

Tidak berbeda jauh dengan di atas, teori "Action Assembly Theory"26 adalah sebuah teori yang menyatakan bahwa sebuah pesan tidak lahir begitu saja, tapi melewati suatu proses tertentu yang -disadari atau tidak disadari oleh pembuatnya-memengaruhi corak pesan tersebut. John Greene dalam teorinya Action Assembly Theory menjelaskan tentang cara seseorang mengorganisasikan pengetahuan dengan pikiran dan menggunakannya untuk membentuk pesan.

Greene menyebut dua komponen pengetahuan yakni pengetahuan isi (content knowledge) dan pengetahuan prosedural (procedural knowledge). You know about things, and you know how to do things (Terjemahan: Anda tahu tentang sesuatu, dan Anda tahu bagaimana melakukan sesuatu itu). Dalam Action Assembly Theory, pengetahuan prosedural procedural knowledge menjadi pusat perhatian utama. Greene menggambarkan cara kerja procedural knowledge seperti titik-titik (node) yang saling terhubung satu sama lain bagaikan website di internet. Node pengetahuan tersebut terutama yang berkaitan dengan perilaku, konsekuensi dan situasi.

Greene memberi contoh ketika kita berjumpa seseorang, biasanya kita akan tersenyum dan mengucapkan, "Hai, apa kabar?" dan kemudian orang ter-

${ }^{24}$ Tokoh yang paling banyak berbicara tentang teori Message Desain Logics adalah O’Keefe, 1988.

${ }^{25}$ Katherine Miller, Communication Theories, hal. 110.

${ }^{26}$ Teori ini dikembangkan oleh John Greene (1984) dan telah dielaborasi dan diuji sejak saat itu. Teori Action Assembly Theory dibangun atas studi Ilmu Komunikasi sosial. Katherine Miller, Communication Theories, hal. 112. 
sebut akan membalasnya dengan berkata, "Baik, bagaimana kabar Anda juga?". Kita menyimpan ini dalam memori sebagai suatu pengetahuan yang saling berhubungan antara situasi menyapa seseorang, tindakan tersenyum, menggunakan kata-kata tertentu, dan mendapatkan hasil berupa balasan sapaan dari orang lain.

Pada kasus yang lebih kompleks, hal-hal yang saling berkaitan semacam itu, di mana pada prosedur tertentu terdapat hubungan yang paling sering digunakan atau yang terakhir digunakan -sehingga menjadi semakin kuat, maka node pengetahuan itu akan membentuk modul-modul atau pola. Greene menyebut modul-modul tersebut sebagai procedural record, yaitu sekumpulan hubungan yang terbentuk oleh node dalam kegiatan jaringan yang cenderung menguat.

Lebih lanjut, Greene juga menjelaskan bahwa jika hubungan pengetahuan tersebut menjelma menjadi beberapa himpunan kegiatan dalam urutan tindakan tertentu yang secara kuat saling berkelompok dan sering digunakan, maka akan menjadi tindakan yang terprogram. Greene mengistilahkan tindakan terprogram ini sebagai "unitilized assemblies". Ritual memberikan salam seperti yang dipaparkan di atas merupakan contoh yang bagus mengenai "unitilized assemblies".

Menurut Greene, tidak ada tindakan tunggal yang dapat berdiri sendiri. Setiap tindakan memengaruhi tindakan yang lain dengan suatu cara tertentu. Untuk memperkenalkan diri misalnya, kita harus menggunakan berbagai tindakan mulai dari tekanan suara dengan kata-kata dan gerakan. Untuk menuliskan paragraf, kita harus menggabungkan berbagai aksi dari pengetahuan yang terkordinasi dalam bahasa untuk menulis atau mengetik.

Tindakan tersebut kemudian diintegrasikan ke dalam jaringan pengetahuan. Setiap bagian pengetahuan merepresentasikan sesuatu untuk melakukannya. Tujuan yang lebih tinggi (seperti melakukan perkenalan) dan yang lebih rendah (seperti tersenyum) digabungkan dalam sebuah hasil representasi yang mengantarkan kita ke suatu tindakan komunikasi. ${ }^{27}$

\section{E. Titik Korelasi Teori Message Production dengan Filsafat Takwil}

Anggapan inti dari konstructivism, seperti telah dijelaskan sebelumnya, adalah bahwa seseorang akan mengambarkan dunia melalui sistem dari gagasan mereka sendiri. Gagasan-gagasan berupa komponen-komponen kognitif yang dilengkapi atas realita-realita yang ada. Kalau kita lihat teori takwil yang dibangun oleh Nasr Hamid, kita bisa menemukan titik kolerasi antara teori konstruktivis-

${ }^{27}$ Katherine Miller, Communication Theories, hal. 112-115 
me dalam ilmu komunikasi. Dikatakan, “Teks merupakan ekspresi perangkat linguistik yang mentransformasikan ide-ide pengarang kepada pembaca. Oleh karena itu dalam rangka untuk sampai pada pemahaman teks yang ideal perlu dipahami perangkat linguistik dan kondisi pengarang karena hubungan antara keduanya adalah hubungan yang bersifat dialektis. Setiap kali teks muncul dalam waktu, maka ia menjadi samar-samar bagi kita sehingga yang terjadi kita lebih dekat kepada kesalah pahaman bukan pada pemahaman yang sebenarnya. ${ }^{28}$

Sedangkan teori Person-Centered Message memposisikian individu sebagai sentral orientasi di samping posisi (kedudukan) sebagai sentral orientasi. ${ }^{29}$ Yang pertama dipakai untuk mengelaborasi simbol-simbol yang mewakili intensi, perasaan dan persepsi seseorang. Sedangkan yang kedua dipakai untuk nenentukan dan membatasi norma-norma dan aturan budaya pada kondisi tertentu. Di sini juga kita bisa menemukan titik kolerasinya dalam tradisi teks seperti yang dikatakan oleh Yusuf Rahman, "Kritik sastra dalam hermeneutik yang berusaha untuk diadopsi sebagai metode penafsiran teks al-Qur'an menjadikan reader centered interpretation yang menekankan pentingya peran pembaca di dalam mencari dan memberikan makna dari suatu teks. Memang terdapat banyak kritikan yang dilontarkan atas teori penafsiran ini karena dikhawatirkan si penafsir akan seenaknya saja memberikan makna yang seseuai dengan latar belakang ideologisnya. ${ }^{30}$ Kalau kita membandingkan keduanya, person centered message memposisikan individu sebagai orientasi sebauh pesan, reader centered interpretation memposisikan pembaca sebagai individu yang memiliki peran salam proses interpretasi sebua teks.

Desain Pesan Logis, salah satu teorinya adalah Expresive Desain Logic, yaitu bahwa bahasa merupakan media untuk mengekspresikan pikiran dan perasaan. Mereka hanya berpikir dan merasakan, yang lainnya akan mengetahui apa yang mereka pikirkan dan rasakan. Kalau kita kembali melihat tradisi teks yang telah dipaparkan, teori ini (bahasa merupakan media untuk mengekspresikan pikiran dan perasaan) sangat erat hubungannya dengan apa yang ada dalam teori penafsiran teks. Dikatakan, "Untuk mengakses makna teks seorang mufassir membutuhkan dua kompetensi, yakni kompetensi linguistik dan kemampuan untuk mengakses alam kemanusiaan. Kompertensi linguistik sendirian tidak cukup karena manusia tidak dapat mengenali wilayah bahasa yang non-defenitif. Demikian pula kompetensi dalam mengakses alam kemanusiaan tidak cukup, karena kompetensi ini tidak pernah sempurna. Oleh karenanya harus berpegang pada kedua aspek ini dalam menafsirkan sebuah teks.

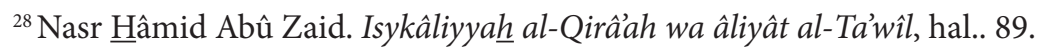

${ }^{29}$ Katherine Miller, Communication Theories, hal. 108.

${ }^{30}$ Sahiron Syamsuddin DKK, Heremeneutika al-Quran, hal. 13.
} 
Kedua aspek di atas (linguistik dan psikis) adalah merupakan perpaduan antara aspek obyektif dan subyektif, dan sangat erat kaitannya pula dengan kajian historis dan strukturalis. Tanpa keduanya seseorang tidak mungkin bisa terhindar dari kesalah-pahaman. Sehingga menurut sclheiermacher signifikansi hermeneutik adalah memahami teks sebagaimana yang dipahami oleh penulisnya, bahkan hingga lebih baik dari apa yang dipahami oleh pengarangnya. ${ }^{31}$

Yang terakhir adalah teori "Action Assembly Theory", 32 teori yang dikembangkan oleh John Greene mengasumsikan bahwa sebuah pesan tidak lahir begitu saja, tapi melewati suatu proses tertentu yang -disadari atau tidak disadari oleh pembuatnya-mempengaruhi corak pesan tersebut. Sepeti yang dikatakan oleh Nasr Hamid, "Bagaimanapun teks agama tidak terpisah dari struktur budaya tempat ia terbentuk. Di samping itu, teks tidak mengesampingkan sama sekali hakikat kebenarannya sebagai teks linguistik. Struktur budaya dijadikan sebagai faktor eksternal teks, sedangkan struktur kebahasaan sebagai faktor internal teks. Faktor-faktor internal ditemukan pada kondisis-kondisi atau problem kultural masyarakat yang menjadi sebab turunnya teks (asbâb an-nuzûl) sedangkan faktor internal ditekankan pada konteks wacana kebahasaan. Kalau kita menggaris bawahi konsep asbâb an-nuzûl di atas, maka sangat erat hubungannya dengan teori yang dikembangkan oleh John Greene ini. Karena dalam konsep asbâb an-nuzûl teks tidak lahir begitu saja, akan tetapi ia diturunkan karena ada persoalan-persoalan tertentu yang ingin dijawab oleh teks, sehingga lahirnya teks tidak terjadi begitu saja, akan tetapi melalaui sebuah proses kontekstualisasi budaya.

\section{F. Kesimpulan}

Wahyu yang diturunkan berupa teks-teks ayat al-Qur'an sejatinya merupakan risâlah atau pesan Allah kepada makhluknya. Risalah yang terdapat dalam proses komunikasi wahyu, baik risalah verbal ataupun nonverbal adalah risalah khusus penerima pertama, namun dituntut untuk disampaikan dan diumumkan kepada manusia. Risalah tersebut berupa perkataan, sebagaimana dalam konteks al-Qur'an. Yang dituntut adalah menyampaikan lafadz risalah tanpa penyimpangan, perubahan atau kekeliruan. Teks membedakan antara pelaku perkataan -pembicaraan, dan pemberi wahyu- dengan penerima pertama secara detail dalam berbagai tempat.

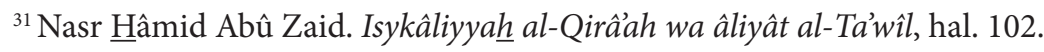

${ }^{32}$ Teori ini dikembangkan oleh John Greene (1984) dan telah dielaborasi dan diuji sejak saat itu. Teori Action Assembly Theory dibangun atas studi Ilmu Komunikasi sosial. Katherine Miller, Communication Theories, hal. 112. 
Berdasarkan dua pendekatan yang digunakan dalam tulisan ini, yaitu takwil dan teori produksi pesan, dapat ditemukan korelasi yang kuat antara keduanya. Baik dalam filsafat takwil Nasr Hâmid Abû Zaid maupun dalam teori komunikasi Katherine Miller, keduanya sama-sama menekankan bahwa untuk memahami pesan dalam bentuk teks, harus menggunakan berbagai instrumen penafsiran dan pemahaman yang meliputi; kemampuan linguistik memahami teks, pertimbangan logis dan tidak logisnya sebuah teks dan kemampuan kontekstualisasi atau asbab an-nuzul sebuah teks. Dengan menggunakan instrumen tersebut, maka akan mengantarkan pada pemahaman ideal dan benar terhadap pesan-pesan teks agama.

\section{Daftar Pustaka}

'Ali Harb, al-Ta’wîl wa al-Haqîqah. Beîrût: al-Markaz as-Tsaqâfiî al-'Arabî, 1992.

Abû Zaid, Nasr Hâmid. an-Nash, as-Sulthah, al-Haqîqah, diindonesiakan menjadi Teks Otoritas Kebenaran. Yogyakarta: LKiS, 2003.

Abû Zaid, Nasr Hâmid. Isykâliyyah al-Qirẩah wa âliyât al-Ta’wîl. Beîrût: al-Markaz as-Tsaqâfiî al-'Arabî, 1994.

Abû Zaid, Nasr Hâmid. Mafhûm An-Nash, Dirâsah fî al-'Ulûm al-Qur'ân. Beirût: Markaz al-Tsaqâf al-'Arabi, 2000.

Az-Zarqani, Muhammad Abdul 'Adhim. Manahil al-'Irfan fi al-'Ulum al-Qur'an, Kairo: Dar Ihya al-Kutub al-Arabiyyah t.th.

Katherine Miller, Communication Theories,Perspectives, Procces, and Contexts. New York: McGraw Hill International Edition, 2005.

Qatthan, Manna' Khalil. Mabahits fi 'Ulumi al-Qur'an. Riyadh: al-Maktabah alMa’arif li an-Nasyr wa at-Tauzi' 1992.

Syamsuddin, Sahiron, DKK. Heremeneutika al-Qur'an. Yogyakarta: Islamika, 2003. 
16 Mumtäz Vol. 1 No. 2, Tahun 2017 